\title{
The antiviral compound BIT225 inhibits HIV-1 replication in myeloid dendritic cells
}

\author{
Gabriela Khoury, Gary Ewart, Carolyn Luscombe, Michelle Miller and John Wilkinson*
}

\begin{abstract}
Background: Previous studies with BIT225 (N-carbamimidoyl-5-(1-methyl-1H-pyrazol-4-yl)-2-naphthamide) have demonstrated a unique antiviral activity that blocks the release of HIV-1 from monocyte-derived macrophages (MDM). Antagonising the ion channel formed by HIV-1 Vpu, BIT225 preferentially targets de novo intracellular virus produced in 'virus-containing compartments' of MDM. In primary infections, dendritic cells (DC) are one of the first cells infected by HIV-1 and can transfer virus to more permissive CD4 ${ }^{+} \mathrm{T}$ cells, making these cells an important target for novel antiviral therapies. To extend previous findings with BIT225, we aimed to further characterise the antiviral activity of BIT225 on HIV-1 replication in monocyte-derived DC (MDDC).

Results: The anti-HIV-1 activity of BIT225 was evaluated in vitro within MDDC alone and in co-cultures with activated $\mathrm{CD}^{+} \mathrm{T}$ cells to examine the effect of the drug on HIV-1 transfer. Antiviral activity was determined by measuring HIV-1 reverse transcriptase activity in the culture supernatant of BIT225 treated and DMSO control cultures. A single dose of BIT225 resulted in a mean (SE) peak inhibition of HIV-1 release from MDDC by $74.5 \%( \pm 0.6)$ following 14 days of culture and a 6-fold reduction of HIV-1 transfer to activated uninfected CD4 ${ }^{+}$T cells in co-culture.

Conclusions: HIV-1 release from MDDC was inhibited by BIT225. This data broadens the drug's antiviral activity profile within cells of the myeloid lineage. These findings suggest a potential role for BIT225 in reducing HIV-1 production and preventing viral dissemination in early and chronic infection and may assist in limiting virus spread with any ongoing viral replication during antiretroviral therapy.
\end{abstract}

Keywords: HIV-1, Antiviral, Myeloid, Dendritic cells, Viral transfer

\section{Findings}

HIV-1 Vpu forms cation-selective ion channels in planar phospholipid bilayers [1] and enhances the process of virion budding and release [2]. BIT225 ( $N$-carbamimidoyl-5-(1-methyl-1H-pyrazol-4-yl)-2-naphthamide), a novel acyl-guanidine, has been shown to inhibit the flow of ions through this viroporin [3]. Further in vitro efficacy studies of BIT225 using HIV-1 infected primary monocyte-derived macrophages (MDM), demonstrated a unique late phase inhibitory mechanism that prevents the release of virus from infected MDM [3, 4]. BIT225 has an $\mathrm{EC}_{50}$ of $2.25 \pm 0.23 \mu \mathrm{M}$ (mean $\pm \mathrm{SE}$ ) with minimal in vitro toxicity $\left(\mathrm{TC}_{50}\right.$ of $\left.284 \mu \mathrm{M}\right)$ in infected MDM, resulting in a selectivity index of 126 . More recently, the

*Correspondence: jwilkinson@biotron.com.au Biotron Limited, Suite 1.9, 56 Delhi Road, North Ryde, Sydney, NSW 2013, Australia
anti-HIV-1 activity of BIT225 towards cells of the myeloid lineage has been examined in vivo and confirms the observed activity in vitro [5]. In $\mathrm{T}$ cells the antiviral activity of BIT225 is 10-fold lower and BIT225 has no inhibitory effect on HIV-2, which lacks Vpu [3]. In further support of BIT225 targeting of Vpu, the antiviral activity of BIT225 in vitro, with cell lines infected with $\Delta \mathrm{Vpu}$ viruses, was found to be minimal [6].

Monocytes, macrophages and dendritic cells (DC) of the myeloid lineage all play important roles in establishing and maintaining HIV-1 infection in vivo. During initial infection both DC and macrophages within the vaginal and gastrointestinal tract mucosa have been shown to be one of the first cells to become infected [7-10]. These cells are able to disseminate virus to other cell types locally, setting up foci of infection [9-11] and in the case of DC, migrate to the lymph nodes and other 
peripheral tissues [8] within $24 \mathrm{~h}$ of infection [12]. DC that enter the lymph node are able to interact and transfer virus to more permissive $\mathrm{CD}^{+} \mathrm{T}$ cells resulting in high levels of virus replication [12-14] and the establishment of long-lived viral reservoirs [15].

In an extension of previous findings on the anti-HIV-1 activity of BIT225 in MDM, the objective of this study was to further characterise the effect of BIT225 on HIV-1 replication in MDDC.

\section{Methods}

\section{Compound}

BIT225 was prepared by dissolving stock in dimethyl sulfoxide (DMSO) and further diluted to working concentrations in culture media. BIT225 was used at a concentration of $20 \mu \mathrm{M}$, approximately ten times the $\mathrm{EC}_{50}$ [3].

\section{Virus}

The laboratory adapted R5-tropic virus $\mathrm{HIV}-1_{\mathrm{BaL}}$, was grown and titred in HIV-1 seronegative peripheral blood mononuclear cells (PBMC) to a TCID $_{50}$ of $8 \times 10^{4}$ infectious doses/mL. Target cells were infected with HIV-1 $1_{\mathrm{BaL}}$ at a multiplicity of infection (MOI) of 0.04 for $3 \mathrm{~h}$.

\section{Generation of MDDC}

PBMC were isolated from seronegative donors (Australian Red Cross Blood Service) via standard Ficoll-Hypaque gradient centrifugation. Total $\mathrm{CD} 14^{+}$monocytes were isolated using magnetic bead depletion, as per manufacturer's guidelines (Miltenyi Biotech, Gladbach, Germany). Isolated $\mathrm{CD}_{14}{ }^{+}$monocytes were cultured with $7.5 \mathrm{ng} /$ $\mathrm{mL}$ GM-CSF and $10 \mathrm{ng} / \mathrm{mL}$ IL-4 (Jomar Bioscience, SA, Australia) for 6 days in RPMI supplemented with $10 \%$ heat inactivated foetal calf serum (FCS; Sigma-Aldrich, St Louis, MO, USA), $20 \mathrm{mM}$ L-glutamine and $200 \mathrm{U} /$ $\mathrm{mL}$ penicillin $/ 200 \mu \mathrm{g} / \mathrm{mL}$ streptomycin (Sigma-Aldrich). Successful differentiation into immature MDDCs was confirmed by flow cytometry, with immature MDDC identified by the loss of CD14 expression and the expression of $\mathrm{CD} 1 \mathrm{a}^{+} \mathrm{CD} 4^{+} \mathrm{DC}-\mathrm{SIGN}^{+} \mathrm{MR}^{+} \mathrm{CD} 83^{-}[12]$.

\section{$\mathrm{CD}^{+} \mathrm{T}$ cell preparation}

PBMC were activated for 3 days with $2.5 \mu \mathrm{g} / \mathrm{mL}$ phytohemmagglutinin (PHA; Sigma-Aldrich) and cultured in RPMI supplemented with $10 \%$ heat-inactivated FCS, $20 \mathrm{mM}$ L-glutamine, $200 \mathrm{U} / \mathrm{mL}$ penicillin $/ 200 \mu \mathrm{g} / \mathrm{mL}$ streptomycin (Sigma-Aldrich) and $20 \mathrm{U} / \mathrm{mL}$ IL-2 (Roche Molecular Biochemicals, Indianapolis, IN). Uninfected activated $\mathrm{CD} 4^{+} \mathrm{T}$ cells used in viral transfer experiments, were isolated using magnetic bead selection with the $\mathrm{CD}^{+}{ }^{+} \mathrm{T}$ cell isolation kit, as per manufacturer's instructions (Miltenyi Biotec) to a purity $>95 \%$.

\section{HIV-1 detection}

Reverse transcriptase (RT) activity assay was used to quantify the amount of virus within the culture supernatants via a chemiluminescent ELISA, which detects the activity of the HIV-1 RT enzyme [16]. Inhibition of HIV-1 infection by BIT225 was determined as a percentage of the infection observed in the DMSO treated controls.

\section{Results}

BIT225 reduces HIV-1 production in MDDC

Day 6 immature MDDC were infected with HIV-1 $1_{\mathrm{BaL}}$ at an MOI of 0.04 for $3 \mathrm{~h}$ and washed three times to remove unbound virus. Infected MDDC were cultured at $1 \times 10^{6}$ cells $/ \mathrm{mL}$ for 14 days in the presence of $20 \mu \mathrm{M}$ BIT225, or the equivalent DMSO solvent control, that was added once at day 0 . Culture supernatants were collected periodically and HIV-1 replication determined by measuring RT activity (Fig. 1a, $\mathrm{n}=3$ ). Despite expected donor-donor variation in the level of HIV-1 infection of the MDDC, the antiviral activity of BIT225 was evident in all three donors compared to the DMSO controls (DMSO v BIT225 at Day 14, $\mathrm{n}=2, \mathrm{p}=0.12$ ). When represented as a mean $( \pm \mathrm{SE})$ percentage of viral inhibition compared to the DMSO controls, the anti-HIV-1 activity of BIT225 increased over time with inhibition at $28.0 \%$ ( \pm 87.9$), 55.3 \%( \pm 12.2), 67.3 \%( \pm 11.0)$, and $74.5 \%$ $( \pm 0.6)$ for days $8,10,11 / 12$ and 14 respectively (Fig. 1b).

\section{BIT225 reduces HIV-1 transfer from infected MDDC to uninfected $\mathrm{CD}^{+}{ }^{+} \mathrm{T}$ cells}

To determine whether BIT225 was able to inhibit the transfer of HIV-1 from the MDDC to a more permissive $\mathrm{CD}^{+} \mathrm{T}$ cell target, infected MDDC were co-cultured with uninfected PHA-activated $\mathrm{CD}^{+}{ }^{+} \mathrm{T}$ cells at 0,2 and $4 \mathrm{~h}$ and at 1, 2, 4, 6, 7, 10, 12 and 14 days post-MDDC infection, at a ratio of $1: 3$ in the presence or absence of BIT225. Co-cultures were maintained for an additional 4-5 days and HIV-1 RT in the culture supernatant measured.

There are two mechanisms by which DC are able to infect $\mathrm{CD}^{+} \mathrm{T}$ cells; firstly, direct transfer of virus to $\mathrm{CD}^{+} \mathrm{T}$ cells via a virological synapse without integration of virus into the DC (in trans), and secondly, postintegration where de novo virus is transferred to the $\mathrm{CD}^{+} \mathrm{T}$ cell from the DC (cis infection) $[12,17]$. HIV-1 viral burden within the intracellular compartments of the infected MDDC is degraded over time by the endolysosomal pathway, with a higher level of virus present within the MDDC at $1 \mathrm{~h}$ versus $8 \mathrm{~h}$ post-infection. The fate of the HIV-1 virion is against the clock to either transfer to a new target cell in trans, within $24 \mathrm{~h}$, or escape the endosome and infect the DC resulting in a productive infection of the host cell [12]. 

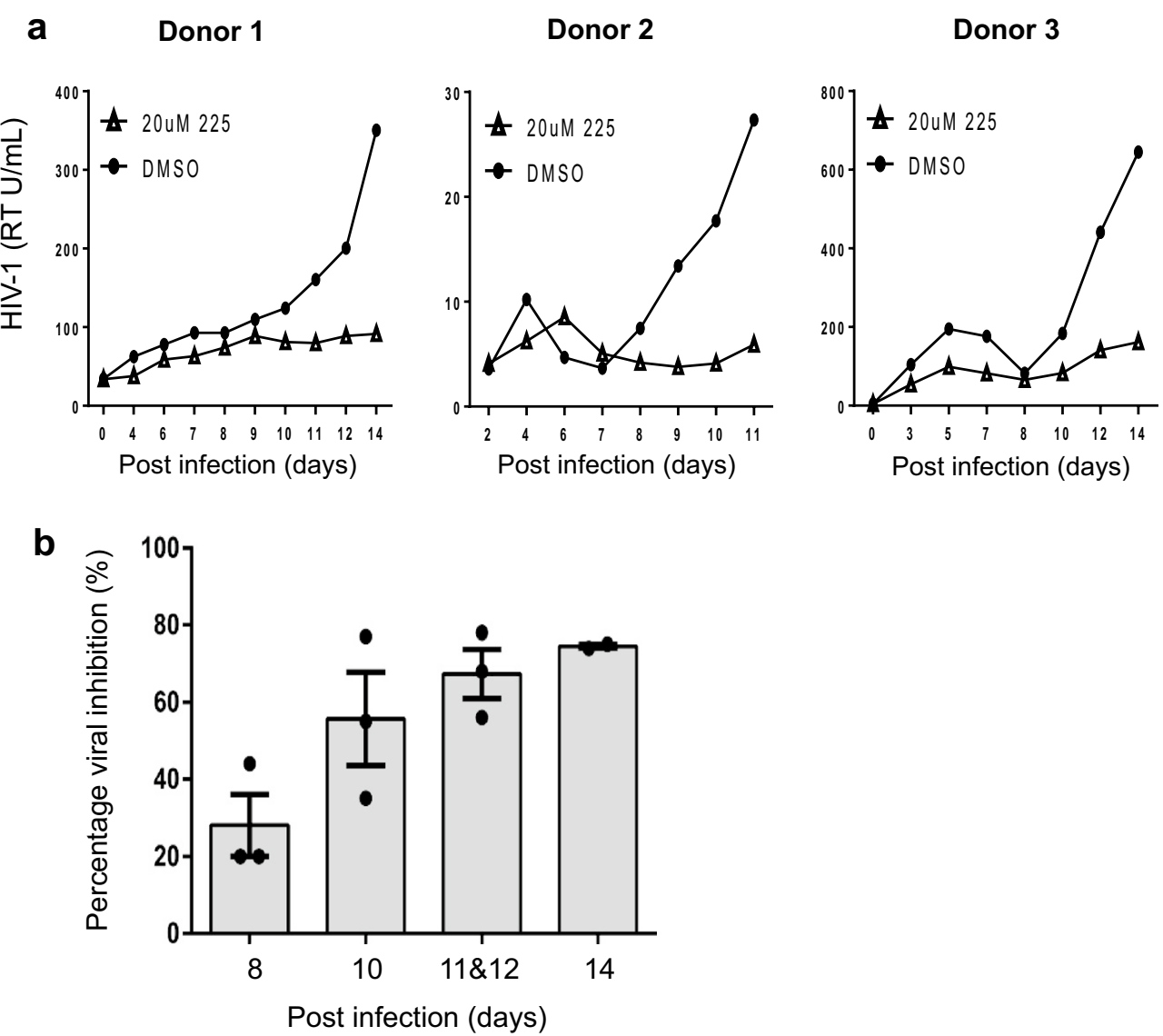

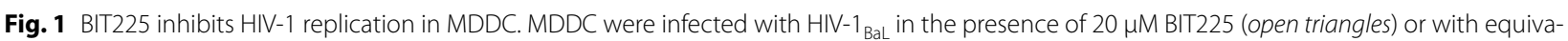
lent DMSO solvent control (full circles). a HIV-1 replication was measured using a reverse transcriptase (RT) activity assay in three separate donors and combined as (b) mean ( \pm SE) percentage viral inhibition

In the co-cultures, a single BIT225 treatment of the infected MDDC resulted in a reduction in the transfer of $\mathrm{HIV}-1$ from the MDDC to the uninfected CD4 ${ }^{+} \mathrm{T}$ cells when the source of HIV-1 was from de novo viral production, cis transfer (Fig. 2a). The antiviral effect of BIT225 increased over time following MDDC infection, such that increased exposure to BIT225 resulted in a decreased virus burden within the MDDC, leading to a reduction in HIV-1 transfer to the more permissive $\mathrm{CD}^{+} \mathrm{T}$ cell (DMSO v BIT225 at Day $12, \mathrm{n}=2, \mathrm{p}=0.12$ ). When MDDC were added to the co-cultures the mean $( \pm \mathrm{SE})$ percentage viral inhibition increased from $32.8 \%$ $( \pm 10.3)$ to $70.5 \%( \pm 20.3)$ between days 2 and 12 postMDDC infection (Fig. 2b).

Further assessment of viral transfer during the $<24 \mathrm{~h}$ time points, trans infection, demonstrated that BIT225 treatment resulted in lower levels of HIV-1 transfer from the MDDC to the uninfected $\mathrm{CD}^{+} \mathrm{T}$ cells in the three donors (Fig. 2a). The mean ( $\pm \mathrm{SE}$ ) percentage inhibition of HIV-1 transfer in trans by BIT225, from the infected
MDDC at 0, 2 and 4 h post infection, was consistent with $37 \%( \pm 17), 37 \%( \pm 13)$ and $36 \%( \pm 12)$ for these three time points (Fig. 2b).

\section{Discussion}

Previous studies have demonstrated that BIT225 is a late phase inhibitor of HIV-1 infection in MDM with antiviral activity in vitro [3,4] and in vivo [5]. The current study demonstrates that a single treatment with BIT225 reduces both the release of HIV-1 and the transfer of de novo virus from MDDC to activated $C D 4^{+} \mathrm{T}$ cells targets and these effects are long-lasting.

Preventing transfer and dissemination of HIV-1 to $\mathrm{CD}^{+} \mathrm{T}$ cells has important implications for both early and late infection events. During early infection, infected DC can transmit HIV-1 to tissue resident $\mathrm{CD}^{+}{ }^{+} \mathrm{T}$ cells at the mucosa or move from the mucosa to the lymph node where they come into contact with $\mathrm{CD} 4^{+} \mathrm{T}$ cells and are able to transmit the virus to these permissive target cells [9-13]. In chronic HIV-1 infection and during 


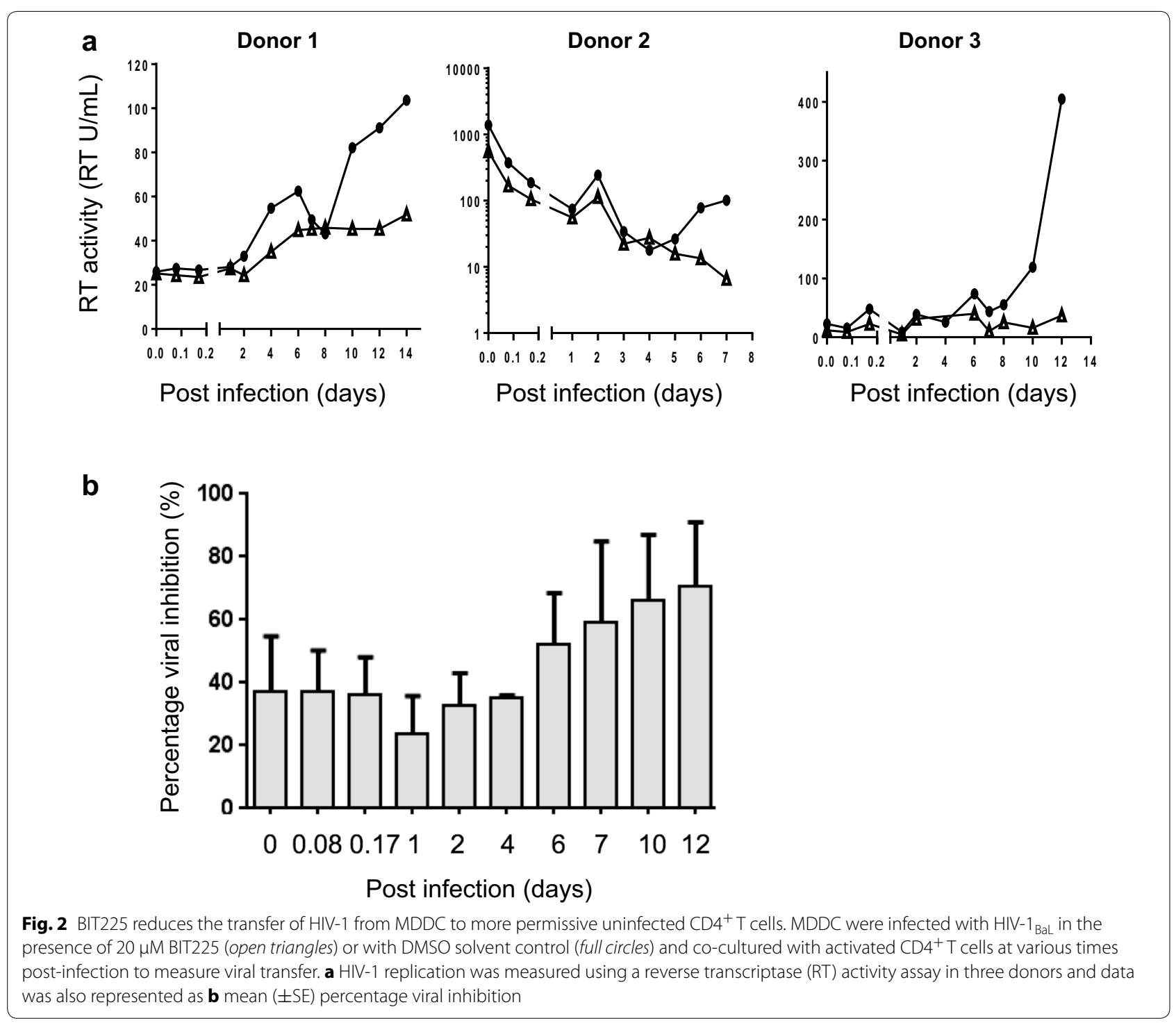

antiretroviral therapy, HIV-1 is detected within follicular DC within the lymph node $[18,19]$ where drug penetration is reduced [20]. These DC are a potential source of new viral infection of both resident follicular helper $\mathrm{T}$ cells [21] and circulating $\mathrm{CD}^{+}{ }^{+} \mathrm{T}$ cells like central memory and naïve $C D 4^{+} \mathrm{T}$ cells [22]. BIT225, as a drug with preferential anti-HIV-1 activity in cells of the myeloid lineage, may be beneficial in targeting ongoing HIV-1 persistence. Although BIT225 can cross the blood-brain barrier [5], the ability of BIT225 to penetrate other drug sanctuary sites to effective levels, such as the lymph nodes, is currently unknown.

In summary, the additional data reported here which further characterise the anti-HIV-1 effect of BIT225 demonstrate that this compound is able to inhibit the release of HIV-1 from MDDC and in turn reduce the transfer of virus from these cells to uninfected $\mathrm{CD}^{+} \mathrm{T}$ cells in co-culture. BIT225 has the potential to play an important role in preventing the dissemination of virus at both early and late stages of infection, limit the establishment of long-lived viral reservoirs in cells of the myeloid lineage and potentially prevent reseeding of the reservoir.

\section{Abbreviations}

CD: cluster of differentiation; DC: dendritic cell; DMSO: dimethyl sulfoxide; $\mathrm{EC}_{50}$ : half maximal effective concentration; ELISA: enzyme-linked immunosorbent assay; FCS: foetal calf serum; GLP: good laboratory practice; GM-CSF: granulocyte-macrophage colony-stimulating factor; HIV-1/2: human immunodeficiency virus type 1/2; L: interleukin; MDDC: monocyte-derived dendritic cell; MDM: monocyte-derived macrophage; MOl: multiplicity of infection; M: molar; PBMC: peripheral blood mononuclear cells; PHA: phytohaemagglutinin; $\mathrm{RT}$ : reverse transcriptase; $\mathrm{SE}$ : standard error; $\mathrm{TCID}_{50}$ : tissue culture infectious dose (resulting in a $50 \%$ response); U: units; Vpu: viral protein unique. 


\section{Authors' contributions}

GK, JW - Conception and design; data acquisition, analysis and interpretation of the results; drafting and revising the manuscript. GE, CL and MM-Conception and design; revising the manuscript. All authors read and approved the final manuscript.

\section{Competing interests}

The authors declare that they have no competing interests.

Received: 2 December 2015 Accepted: 26 January 2016

Published online: 08 February 2016

\section{References}

1. Ewart GD, Sutherland T, Gage PW, Cox GB. The Vpu protein of human immunodeficiency virus type 1 forms cation-selective ion channels. J Virol. 1996;70:7108-15.

2. Ewart GD, Mills K, Cox GB, Gage PW. Amiloride derivatives block ion channel activity and enhancement of virus-like particle budding caused by HIV-1 protein Vpu. Eur Biophys J. 2002;31:26-35.

3. Khoury G, Ewart G, Luscombe C, Miller M, Wilkinson J. Antiviral efficacy of the novel compound BIT225 against HIV-1 release from human macrophages. Antimicrob Agents Chemother. 2010;54:835-45.

4. Ewart GD, Nasr N, Naif H, Cox GB, Cunningham AL, Gage PW. Potential new anti-human immunodeficiency virus type 1 compounds depress virus replication in cultured human macrophages. Antimicrob Agents Chemother. 2004:48:2325-30

5. Wilkinson J, Ewart G, Luscombe C, McBride K, Ratanasuwan W, et al. A Phase $1 \mathrm{~b} / 2 \mathrm{a}$ study of the safety, pharmacokinetics and antiviral activity of BIT225 in patients with HIV-1 infection. J Antimicrob Chemother. 2015; doi:10.1093/jac/dkv389.

6. Kuhl BD, Cheng V, Donahue DA, Sloan RD, Liang C, Wilkinson J, Wainberg MA. The HIV-1 Vpu viroporin inhibitor BIT225 does not affect Vpu-mediated tetherin antagonism. PLoS ONE. 2011;6:e27660.

7. Shen R, Richter HE, Clements RH, Novak L, Huff K, Bimczok D, et al. Macrophages in vaginal but not intestinal mucosa are monocyte-like and permissive to human immunodeficiency virus type 1 infection. J Virol. 2009;83:3258-67.

8. Shen R, Kappes JC, Smythies LE, Richter HE, Novak L, Smith PD. Vaginal myeloid dendritic cells transmit founder HIV-1. J Virol. 2014;88:7683-8.

9. Ballweber L, Robinson B, Kreger A, Fialkow M, Lentz G, McElrath MJ, Hladik F. Vaginal langerhans cells nonproductively transporting HIV-1 mediate infection of T cells. J Virol. 2011;85:13443-7.
10. Hladik F, Sakchalathorn P, Ballweber L, Lentz G, Fialkow M, Eschenbach D, McElrath MJ. Initial events in establishing vaginal entry and infection by human immunodeficiency virus type-1. Immunity. 2007;26:257-70.

11. Miller CJ, Li Q, Abel K, Kim EY, Ma ZM, Wietgrefe S, et al. Propagation and dissemination of infection after vaginal transmission of simian immunodeficiency virus. J Virol. 2005;79:9217-27.

12. Turville SG, Santos JJ, Frank I, Cameron PU, Wilkinson J, Miranda-Saksena $M$, et al. Immunodeficiency virus uptake, turnover, and 2-phase transfer in human dendritic cells. Blood. 2004;103:2170-9.

13. Cameron PU, Freudenthal PS, Barker JM, Gezelter S, Inaba K, Steinman RM. Dendritic cells exposed to human immunodeficiency virus type-1 transmit a vigorous cytopathic infection to CD4 + T cells. Science. 1992:257:383-7.

14. Loré K, Smed-Sörensen A, Vasudevan J, Mascola JR, Koup RA. Myeloid and plasmacytoid dendritic cells transfer HIV-1 preferentially to antigenspecific CD4 + T cells. J Exp Med. 2005;201:2023-33.

15. Haase AT, Henry K, Zupancic M, Sedgewick G, Faust RA, Melroe H, et al. Quantitative image analysis of HIV-1 infection in lymphoid tissue. Science. 1996;274:985-9.

16. Suzuki K, Craddock BP, Okamoto N, Kano T, Steigbigel RT. Poly A-linked colorimetric microtiter plate assay for HIV reverse transcriptase. J Virol Methods. 1993;44:189-98.

17. Sharova N, Swingler C, Sharkey M, Stevenson M. Macrophages archive HIV-1 virions for dissemination in trans. EMBO J. 2005:24:2481-9.

18. Spiegel H, Herbst H, Niedobitek G, Foss HD, Stein H. Follicular dendritic cells are a major reservoir for human immunodeficiency virus type 1 in lymphoid tissues facilitating infection of CD4 + T-helper cells. Am J Pathol. 1992;140:15-22.

19. Coleman CM, Wu L. HIV interactions with monocytes and dendritic cells: viral latency and reservoirs. Retrovirology. 2009;6:51.

20. Fletcher CV, Staskus K, Wietgrefe SW, Rothenberger M, Reilly C, Chipman $J G$, et al. Persistent HIV-1 replication is associated with lower antiretroviral drug concentrations in lymphatic tissues. Proc Natl Acad Sci USA. 2014;111:2307-12.

21. Perreau M, Savoye AL, De Crignis E, Corpataux JM, Cubas R, Haddad EK, et al. Follicular helper T cells serve as the major CD4 T cell compartment for HIV-1 infection, replication, and production. J Exp Med. 2013;210:143-56.

22. Chomont N, El-Far M, Ancuta P, Trautmann L, Procopio FA, Yassine-Diab $B$, et al. HIV reservoir size and persistence are driven by $T$ cell survival and homeostatic proliferation. Nat Med. 2009;15:893-900.

\section{Submit your next manuscript to BioMed Central and we will help you at every step:}

- We accept pre-submission inquiries

- Our selector tool helps you to find the most relevant journal

- We provide round the clock customer support

- Convenient online submission

- Thorough peer review

- Inclusion in PubMed and all major indexing services

- Maximum visibility for your research

Submit your manuscript at www.biomedcentral.com/submit
() Biomed Central 